(c) American Dairy Science Association, 2005.

\title{
Effect of Selenium Source on Selenium Status, Neutrophil Function, and Response to Intramammary Endotoxin Challenge of Dairy Cows*
}

\author{
W. P. Weiss and J. S. Hogan \\ Department of Animal Sciences, Ohio Agricultural Research and Development Center, \\ The Ohio State University, Wooster 44691
}

\begin{abstract}
The effects of feeding dry and early lactation dairy cows diets with selenate or selenized yeast (Se-yeast) on concentrations of Se in serum, milk, and newborn calves, neutrophil function, and inflammatory response were determined. At $60 \mathrm{~d}$ before anticipated calving until approximately $30 \mathrm{~d}$ in milk (DIM), cows were fed diets that contained $0.3 \mathrm{mg}$ of supplemental Se/kg of DM from sodium selenate or Se-yeast. Diets also contained $0.2 \%$ supplemental $\mathrm{S}$ (as sulfate) because it has been shown to reduce absorption of Se by dairy cows. The concentration of Se in serum at calving and 28 DIM was about 1.4 times greater for cows fed Se-yeast than for those fed selenate. Serum concentrations decreased 45 and 23\% from dry-off to calving for cows fed selenate or Se-yeast, respectively. Selenium concentrations in serum from newborn calves were also about 1.4 times greater when the dams were fed Se-yeast. Concentrations of Se in colostrum and milk were about 1.8 times greater when cows were fed Se-yeast. Blood neutrophils were isolated from cows at $28 \mathrm{DIM}$ and were used in an in vitro kill assay. Selenium treatment did not affect bacterial kill or the percentage of neutrophils that phagocytized bacteria. At approximately 28 DIM, one quarter from each cow was infused with a solution containing endotoxin. Peak body temperature $\left(40.7^{\circ} \mathrm{C}\right)$ occurred $6 \mathrm{~h}$ postinfusion, and peak somatic cell count $\left(6.5 \log _{10} / \mathrm{mL}\right)$ occurred at $12 \mathrm{~h}$ postinfusion. Neither measure was influenced by Se treatment.
\end{abstract}

(Key words: selenium, neutrophils, mastitis, dairy cow)

\footnotetext{
Abbreviation key: GSH-px = glutathionine peroxidase; Se-Met = seleno-methionine.

Received May 19, 2005.

Accepted August 21, 2005.

Corresponding author: W. P. Weiss; e-mail: weiss.6@osu.edu.

*Salaries and research support provided by state and federal funds appropriated to the Ohio Agricultural Research and Development Center, The Ohio State University. Additional funds provided Lallemand Inc., Milwaukee, WI. Manuscript 17-05AS.
}

\section{INTRODUCTION}

Selenium can be supplemented to cattle diets in inorganic (usually sodium salts of selenite or selenate) or organic forms (Se-yeast). Selenium-yeast is produced by growing specific strains of yeast in a Se-enriched media. Although the distribution of Se compounds in yeast varies among sources, Seleno-methionine (SeMet) is usually the predominant form of Se, but selenocysteine and numerous other seleno-compounds are also found (Rayman, 2004).

Concentrations of Se in serum and whole blood have been used as an index of Se status because, in general, increased concentrations of Se in serum or whole blood have been related to reduced SCC, reduced mastitis, and improved neutrophil function (Smith et al., 1984; Erskine et al., 1987; Weiss et al., 1990a; Cebra et al., 2003). Cattle fed Se-yeast usually have higher concentrations of Se in whole blood, serum (or plasma), and milk than do those fed inorganic Se (Nicholson et al., 1991b; Knowles et al., 1999; Ortman and Pehrson, 1999; Gunter et al., 2003). Studies that found relationships between immunological or clinical measures and blood concentrations of Se used inorganic Se. Whether the typically higher concentrations of Se in blood when cows are fed Se-yeast reflect improved Se status (i.e., improved disease resistance) compared with cows fed inorganic Se is unknown.

Factors other than Se intake and Se source can influence Se concentrations in tissues and clinical and immunological responses. Increased intake of sulfate by cows reduces apparent absorption of Se (from selenate), resulting in reduced plasma concentrations of Se (Ivancic and Weiss, 2001). Different systems are used for intestinal absorption of Se-Met (same mechanism as used from methionine) and inorganic Se (Vendeland et al., 1992). Sulfate is less likely to interfere with absorption of Se from Se-yeast than with absorption of inorganic Se. Vitamin E and Se are involved with cellular antioxidant status and increased intake of vitamin $\mathrm{E}$ can reduce responses to Se supplementation (Hogan et al., 1990).

We hypothesized that cows fed Se-yeast during the dry period and early lactation would have higher con- 
Table 1. Ingredient composition of diets fed during the experiment (\% of DM).

\begin{tabular}{|c|c|c|c|}
\hline Ingredient & $\begin{array}{l}\text { Dry } \\
\text { period }\end{array}$ & $\begin{array}{l}\text { Prefresh } \\
\text { period }\end{array}$ & $\begin{array}{l}\text { Lactation } \\
\text { period }\end{array}$ \\
\hline Grass silage & 41.5 & - & - \\
\hline Grass hay, long & 15.0 & 10.0 & - \\
\hline Corn silage & 26.0 & 30.0 & 35.0 \\
\hline Alfalfa silage & - & 25.0 & 20.0 \\
\hline Corn grain, ground & 5.70 & 22.30 & 22.20 \\
\hline Soybean hulls & 6.90 & 7.55 & - \\
\hline Soybean meal, $44 \% \mathrm{CP}$ & 3.20 & 3.00 & 7.00 \\
\hline Soybean meal, treated ${ }^{1}$ & - & - & 5.10 \\
\hline Animal-vegetable fat & 0.17 & 0.35 & 0.33 \\
\hline Soybeans, whole roasted & - & - & 8.00 \\
\hline Magnesium sulfate & 0.65 & 0.84 & 0.81 \\
\hline Calcium sulfate & 0.36 & 0.42 & 0.45 \\
\hline Dicalcium phosphate & 0.04 & 0.03 & 0.20 \\
\hline Trace mineral salt & 0.17 & 0.20 & 0.40 \\
\hline Sodium bicarbonate & - & - & 0.24 \\
\hline Selenium premix ${ }^{2}$ & 0.14 & 0.14 & 0.14 \\
\hline Mineral-vitamin premix ${ }^{3}$ & 0.17 & 0.17 & 0.13 \\
\hline
\end{tabular}

${ }^{1}$ Surepro, Land O'Lakes, Inc. (St. Paul, MN).

${ }^{2}$ The premix in diets with selenate contained $200 \mathrm{mg}$ of Se from sodium selenate/kg. The premix in diets with Se-yeast contained 10\% Alkosel (2000 mg of Se/kg; Lallemand, Inc., Milwaukee, WI) and 90\% ground corn.

${ }^{3}$ For dry cow and prefresh diets, premix contained $3230 \mathrm{mg}$ of $\mathrm{Cu}$ (copper sulfate), $4650 \mathrm{mg}$ of $\mathrm{Zn}$ (zinc sulfate), $3400 \mathrm{kIU}$ of vitamin $\mathrm{A}, 980 \mathrm{kIU}$ of vitamin D, and $23 \mathrm{kIU}$ of vitamin E/ kg. For the lactation diets, the premix contained $6370 \mathrm{mg}$ of $\mathrm{Cu}, 13,250 \mathrm{mg}$ of $\mathrm{Zn}, 3740$ $\mathrm{kIU}$ of vitamin A, $1140 \mathrm{kIU}$ of vitamin D, and $19 \mathrm{kIU}$ of vitamin E/ $\mathrm{kg}$.

centrations of Se in blood serum than cows fed selenate and that these higher concentrations would reflect improved Se status. The increased Se status would result in improved neutrophil function and an enhanced inflammatory response. Because of the relationships between Se and vitamin $\mathrm{E}$ and between Se and sulfate, we further hypothesized that these differences would be magnified when the basal diets provided less than recommended amounts of vitamin $\mathrm{E}$ and excessive amounts of sulfate.

\section{MATERIALS AND METHODS}

Holstein cows $(\mathrm{n}=22)$ and heifers $(\mathrm{n}=18)$ were grouped by parity and anticipated calving date into 20 blocks of 2 animals each. At $60 \mathrm{~d}$ before anticipated calving, cows were dried off, and cows and heifers moved to one of two identical group pens. The diets fed to both groups were identical except one contained Seyeast (Alkosel, Lallemand Inc., Milwaukee, WI) and the other contained sodium selenate (Tables 1 and 2). Both diets were formulated to provide $0.3 \mathrm{mg}$ of supplemental Se/kg. The diets were formulated to meet the requirements (NRC, 2001) of a dry cow except that they provided only about 500 IU of supplemental vitamin E/ d [50\% less than NRC (2001) recommendations] and contained $0.2 \%$ supplemental S (from a mixture of calcium and magnesium sulfate). Cows remained in their respective pens until approximately $1 \mathrm{wk}$ before anticipated calving. They were then moved into individual box stalls and fed a prefresh period diet (Tables 1 and 2 ), but the source and concentration of supplemental Se remained the same as that fed during the dry period. Approximately $3 \mathrm{~d}$ after calving, cows were moved to individual tie stalls and fed a lactation diet (Tables 1 and 2). Cows received the same source and concentration of supplemental Se as they did during the dry period. When moved to the tie stalls, cows were fed once daily and milked twice daily. Milk samples (a.m. and p.m.) were taken once weekly during the first 21 DIM and analyzed for fat and true protein using infrared analysis (DHI Cooperative, Inc., Columbus, OH). Animals were weighed on $-60 \mathrm{~d}$, when moved to the maternity stalls (approximately $3 \mathrm{~d}$ before calving), 3 $\mathrm{d}$ postcalving, and on $7 \mathrm{~d}$ after they were challenged with LPS (approximately 35 DIM). All calves were weighed $3 \mathrm{~d}$ after birth, and female calves ( $\mathrm{n}=9$ and 8 , respectively, for selenate and Se-yeast groups) were weighed at weaning. During the first $3 \mathrm{~d}$ after birth, calves were fed only colostrum from their dam $(4 \mathrm{~L} / \mathrm{d}$ divided into 2 equal feedings). Female calves were fed a common diet (milk replacer and starter) from $3 \mathrm{~d}$ of age until weaning. Weaning occurred when calves consumed $0.7 \mathrm{~kg}$ of a DM from a starter grain mix.

At approximately $28(\mathrm{SD}=7.1) \mathrm{DIM}$, either the right or left front mammary quarter from each cow was infused with LPS by intramammary infusion via the teat canal. Infusions were $3 \mathrm{~h}$ after morning milking. Only uninfected quarters were infused. Concentrated LPS was purchased (Escherichia coli O26:B6, Sigma Chemical Co., St. Louis, MO), diluted in PBS, and sterilized by passage through $0.2-\mu \mathrm{m}$ pore filters. Challenge inoculum was $10 \mu \mathrm{g}$ of LPS in $10 \mathrm{~mL}$ of PBS. Milk samples were collected from challenged and unchallenged quarters at $2,4,6,8,10,12,24,48,72$, and $96 \mathrm{~h}$ after challenge to determine speed and magnitude of intramammary neutrophil response. The SCC per milliliter of milk were determined with a Bentley Somatocount 150 milk somatic cell counter (Bentley Instruments, Inc., Chaska, MN). Samples from clinical quarters were diluted 1:10 and 1:50 (milk:PBS, vol/vol) for counting. Data were expressed as $\log _{10} \mathrm{SCC} / \mathrm{mL}$ of milk. Rectal temperatures were measured immediately before challenge and at each time that quarter foremilk samples were collected post-challenge.

Neutrophil phagocytosis and intracellular kill of Escherichia coli 487 were determined from blood neutrophils isolated immediately prior to intramammary LPS challenge. Phagocytosis and intracellular kill of bacteria by neutrophils were measured by modifica- 
Table 2. Nutrient composition of diets fed during the experiment (DM basis).

\begin{tabular}{|c|c|c|c|c|c|c|}
\hline & \multicolumn{2}{|c|}{ Dry period } & \multicolumn{2}{|c|}{ Prefresh period } & \multicolumn{2}{|c|}{ Lactation period } \\
\hline & Selenate & Se-yeast & Selenate & Se-yeast & Selenate & Se-yeast \\
\hline $\mathrm{CP}, \%$ & 13.1 & 13.2 & 12.7 & 12.7 & 17.4 & 17.4 \\
\hline $\mathrm{NDF}, \%$ & 52.2 & 52.4 & 39.0 & 39.3 & 31.1 & 31.0 \\
\hline $\mathrm{Ca}, \%$ & 0.57 & 0.49 & 0.59 & 0.54 & 0.58 & 0.57 \\
\hline $\mathrm{P}, \%$ & 0.28 & 0.28 & 0.27 & 0.27 & 0.39 & 0.38 \\
\hline $\mathrm{Mg}, \%$ & 0.25 & 0.26 & 0.27 & 0.27 & 0.26 & 0.26 \\
\hline $\mathrm{K}, \%$ & 1.92 & 1.92 & 1.60 & 1.60 & 1.55 & 1.54 \\
\hline $\mathrm{S}, \%$ & 0.29 & 0.29 & 0.34 & 0.33 & 0.33 & 0.35 \\
\hline $\mathrm{Cu}, \mathrm{mg} / \mathrm{kg}$ & 12 & 13 & 16 & 13 & 17 & 15 \\
\hline $\mathrm{Fe}, \mathrm{mg} / \mathrm{kg}$ & 269 & 265 & 239 & 246 & 240 & 231 \\
\hline $\mathrm{Mn}, \mathrm{mg} / \mathrm{kg}$ & 60 & 58 & 44 & 43 & 44 & 42 \\
\hline $\mathrm{Zn}, \mathrm{mg} / \mathrm{kg}$ & 42 & 40 & 44 & 43 & 62 & 61 \\
\hline $\mathrm{Se},{ }^{1} \mathrm{mg} / \mathrm{kg}$ & 0.36 & 0.34 & 0.40 & 0.35 & 0.46 & 0.40 \\
\hline
\end{tabular}

\footnotetext{
${ }^{1}$ The average Se concentrations in the grass hay, grass silage, corn silage, alfalfa silage, and roasted
} soybeans used in the diets were $0.050,0.032,0.016,0.022$, and $0.065 \mathrm{mg} / \mathrm{kg}$ of DM.

tions of the fluorochrome assay described by Goldner et al. (1983). Neutrophils were collected and bacteria were prepared as described by Hogan et al. (1992). Briefly, bacteria were cultured to a stationary phase of growth, washed, and opsonized in 10\% heat-inactivated serum for $20 \mathrm{~min}$. Suspensions of neutrophils and opsonized bacteria were added to incubation tubes in a ratio of 1:2 (neutrophils:bacterial colony forming units) and incubated at $100 \mathrm{rpm}$ for $90 \mathrm{~min}$. Phagocytic index was calculated as average number of bacteria phagocytosed per neutrophil. Intracellular kill was determined as [number of dead phagocytosed bacteria/(number of live + number of dead intracellular bacteria) $] \times 100$. Percentages of neutrophils phagocytizing were calculated as the number of neutrophils with at least one intracellular bacteria divided by total number of neutrophils $\times$ 100. All assays were conducted in duplicate and conducted blind relative to laboratory personnel having prior knowledge of cow or treatment.

Blood was sampled from all animals at $60 \mathrm{~d}$ before anticipated calving $(-60 \mathrm{~d})$, within $12 \mathrm{~h}$ after calving $(0 \mathrm{~d})$, and immediately before challenge (approximately 28 DIM; 28 d). Blood from calves was sampled within $12 \mathrm{~h}$ of birth before calves consumed colostrum and again at $3 \mathrm{~d}$ of age (after 5 or 6 feedings of colostrum from their dam). Calves were fed twice daily at the rate of $2 \mathrm{~L}$ per feeding. Blood samples were allowed to clot, and serum was removed and frozen. First milking colostrum and milk at $28 \mathrm{~d}$ (pre-challenge) were sampled and frozen. Milk from the challenged quarter was sampled at 24 and $96 \mathrm{~h}$ post-challenge and frozen. The concentration of Se in feeds, serum, milk, and colostrum was measured using a fluorometric method (Koh and Benson, 1983) after digestion in a mixture of nitric and 11.6 $M$ perchloric acids (4:1, vol/vol). Appropriate standards and National Institute of Standards and Technology (Gaithersburg, MD) reference materials (milk pow- der, NIST \#1549; bovine liver, NIST \#1577b) were analyzed with each run.

Feeds were sampled weekly and composited by month (6 or 7 composite samples per feed). Silages were analyzed weekly for $\mathrm{DM}\left(100^{\circ} \mathrm{C}\right.$ oven for $\left.24 \mathrm{~h}\right)$ to adjust TMR for changes in moisture concentrations. Monthly samples of silages were lyophilized, and all feed samples were ground through a 1-mm screen (Wiley mill, Arthur Thomas, Philadephia, PA). Ground samples were analyzed for $\mathrm{DM}\left(100^{\circ} \mathrm{C}\right.$ oven for $\left.24 \mathrm{~h}\right)$, ash $\left(600^{\circ} \mathrm{C}\right.$ muffle oven overnight), NDF using sulfite and amylase $\left(\right.$ Ankom $^{200}$ Fiber Analyzer, Ankom Technology, Fairport, NY), CP (AOAC, 1990) and P, K, Ca, $\mathrm{Mg}, \mathrm{S}, \mathrm{Cu}, \mathrm{Fe}$, $\mathrm{Mn}$, and Zn using inductively coupled plasma emission spectroscopy after a nitric-perchloric acid digestion of concentrates and a dry-ashing of forages.

Of the 40 animals initially enrolled in this experiment, 34 were sampled for the neutrophil function assay and were challenged ( $\mathrm{n}=16$ and 18 for Selenate and Se-yeast groups, respectively). Three cows were not used because the mammary gland was infected, and three cows had other health problems (severe ketosis, milk fever, and a leg injury). Because of problems during cell isolation for the neutrophil function assay, two samples could not be used, resulting in 15 and 17 (Selenate and Se-yeast, respectively) usable observations. After the animal portion of the experiment was completed, a subset of 10 blocks of animals that were challenged were randomly selected for Se analysis of serum, colostrum, milk ( $1 \mathrm{~d}$ pre-challenge and 24 and $96 \mathrm{~h}$ postchallenge), and serum from calves. Based on previous experiments, 10 samples per treatment provided adequate statistical power to test treatment differences for Se concentrations serum and milk.

All statistical analyses were conducted using Proc MIXED (SAS, 1999) with treatment as a fixed effect (1 df) and block as a random effect (9 df for blood and 
Table 3. Effect of Se source on concentrations (mg/L) of Se in serum from dam and calf and in colostrum and milk. ${ }^{1}$

\begin{tabular}{|c|c|c|c|c|c|c|}
\hline & \multirow[b]{2}{*}{ Selenate } & \multirow[b]{2}{*}{ Se-yeast } & \multirow[b]{2}{*}{ SEM } & \multicolumn{3}{|c|}{$P<^{2}$} \\
\hline & & & & Trt & Day & $\mathrm{T} * \mathrm{D}$ \\
\hline Cow serum & & & & 0.001 & 0.01 & 0.01 \\
\hline$-60 \mathrm{~d}$ & 0.079 & 0.077 & 0.005 & NS & - & - \\
\hline $0 \mathrm{~d}$ & 0.043 & 0.059 & 0.005 & 0.01 & - & - \\
\hline $28 \mathrm{~d}$ & 0.054 & 0.074 & 0.005 & 0.01 & - & - \\
\hline Calf serum & & & & 0.001 & 0.01 & 0.20 \\
\hline$\leq 12 \mathrm{~h}$ & 0.039 & 0.054 & 0.002 & 0.01 & - & - \\
\hline $3 \mathrm{~d}$ & 0.042 & 0.062 & 0.002 & 0.01 & - & - \\
\hline Milk & & & & 0.001 & 0.001 & 0.001 \\
\hline Colostrum & 0.087 & 0.151 & 0.007 & 0.01 & - & - \\
\hline $1 \mathrm{~h}$ pre-challenge & 0.019 & 0.039 & 0.007 & 0.01 & - & - \\
\hline $24 \mathrm{~h}$ post-challenge & 0.027 & 0.041 & 0.007 & 0.01 & - & - \\
\hline $96 \mathrm{~h}$ post-challenge & 0.021 & 0.040 & 0.007 & 0.01 & - & - \\
\hline
\end{tabular}

${ }^{1}$ Samples of serum from cows expressed as day relative to calving. Samples of serum from calves expressed as time after birth. For milk samples, colostrum was coded as $\mathrm{d} 1$. Milk samples taken $1 \mathrm{~h}$ before the mammary gland was infused with LPS were coded as $28 \mathrm{~d}$, and the 24 -h and 96 -h postchallenge samples were coded as d 29 and d 32 , respectively.

${ }^{2}$ Data were analyzed within a sample type as a repeated measure with treatment (Trt), day, and the treatment by day $\left(\mathrm{T}^{*} \mathrm{D}\right)$ interaction included in the model and within each day. $\mathrm{NS}=P>0.15$.

milk Se data and $17 \mathrm{df}$ for production, challenge, and neutrophil function data). Selenium concentration data underwent two different statistical analyses. The first analysis was conducted within each sample day ( $3 \mathrm{~d}$ for cow serum, $2 \mathrm{~d}$ for calf serum, and $4 \mathrm{~d}$ for milk; colostrum was included in the milk analysis), and the model included treatment, block, and error. The second analysis was conducted to examine the interaction between time and treatment, and the model included treatment, block, day (repeated, fixed, with 2,1 , and 3 $\mathrm{df}$ for cow serum, calf serum, and milk, respectively), treatment $\times$ day (fixed), and error. Production (from 3 DIM to 4 post-challenge) and neutrophil function data were analyzed using a model that included treatment, block, and error (13 df). Daily milk yield and DMI data during the challenge (from $4 \mathrm{~d}$ pre- until $4 \mathrm{~d}$ post-challenge) were analyzed as repeated measures with block, treatment, day, treatment $\times$ day, and error included in the model. For all analyses using repeated measures, compound symmetry was used to describe the error structure. Clinical responses to endotoxin challenge (body temperature and SCC) could not be analyzed as repeated measures because of infinite likelihood; therefore, data were analyzed within each time point with a model that included treatment, block, and error (13 df). Correlations between certain variables were calculated using Proc CORR (SAS, 1999).

\section{RESULTS AND DISCUSSION}

\section{Serum Se}

Before the experiment started, all animals (cows and heifers) had been fed diets that contained approxi- mately $0.3 \mathrm{mg}$ of supplemental Se (from sodium selenate)/kg of DM for at least 12 mo. Concentrations of Se in serum collected at $-60 \mathrm{~d}$ (Table 3 ) were not different between treatments and would be considered to represent adequate status for dairy cows (Stowe and Herdt, 1992). Concentrations of Se in serum at calving were less than those at dry-off for both groups and lower than recommended (Stowe and Herdt, 1992), but concentrations were greater $(P<0.01)$ for cows fed Se-yeast than for those fed selenate. In a previous experiment, plasma concentrations of Se did not decrease over the dry period when cows were fed diets with approximately $0.3 \mathrm{mg}$ of supplemental Se/kg from selenate and no supplemental S (Weiss et al., 1990b). Diets in the current study were formulated to contain $0.2 \%$ supplemental S (from sulfate) as an antagonist of Se and likely contributed to reduced Se concentrations observed at calving (Ivancic and Weiss, 2001). Concentrations of serum Se increased $(P<0.05)$ after calving for both groups, but serum Se was still less at 28 DIM than at $-60 \mathrm{~d}$ for cows fed selenate. Based on reference values using the same analytical method for measuring serum Se as used in this experiment (Stowe and Herdt, 1992), Se status of cows in the Se-yeast group was adequate, but status was less than optimal for cows in the selenate group. At 28 DIM, concentrations of serum Se were greater $(P<0.01)$ for cows fed Se-yeast than those fed selenate. At calving and 28 DIM, serum Se concentrations were approximately $37 \%$ greater for cows fed Seyeast than for those fed selenate. When data from -60 $\mathrm{d}$ (before treatments were imposed) was included, a day by treatment interaction was observed $(P<0.01)$ but not when the $-60 \mathrm{~d}$ data were excluded $(P>0.60)$. Treat- 
ment had the same relative effect on serum Se concentrations on both d 0 and 28 , but Se concentrations did not decrease as much for cows fed Se-yeast compared with those fed selenate when switched from a diet with $0.3 \mathrm{mg}$ of supplemental Se/kg and no supplemental sulfate to treatment diets.

\section{Colostrum and Milk Se}

Days in milk (colostrum was coded as 1), treatment, and the treatment $\times$ day interaction had significant $(P$ $<0.01$ ) effects on the concentrations of Se in milk (Table $3)$. The day effect was mostly caused by differences between colostrum and milk. For both treatments, the concentration of Se in colostrum was approximately 3.8 times greater $(P<0.01)$ than the concentration in milk. Colostrum was expected to have much greater concentrations of Se than milk (Abdelrahman and Kincaid, 1995; Awadeh et al., 1998). Selenium concentration in milk taken from the gland $24 \mathrm{~h}$ after it was infused with LPS was greater $(P<0.06)$ than in milk taken before challenge and $96 \mathrm{~h}$ post-challenge. The increase in Se concentration in milk following challenge could have been caused by the influx of neutrophils into the gland. Bovine blood neutrophils have extremely high glutathionine peroxidase (GSH-px) activity (Scholz and Hutchinson, 1979). The influx of neutrophils (i.e., somatic cells; Figure 1) into the gland following LPS challenge could have been responsible for the increase in Se concentration in milk. However, the concentration of Se in milk returned to pre-challenge concentrations by $96 \mathrm{~h}$ post-challenge, but SCC remained elevated. The populations of immune cells that comprise SCC change during the course of an inflammatory event and this could explain why Se concentrations returned to baseline while SCC remained elevated.

The concentrations of Se in colostrum and milk were typical for both selenate and Se-yeast treatments (Abdelrahman and Kincaid, 1995; Malbe et al., 1995). The concentrations of Se in colostrum and milk were 1.5 to 2.0 times greater $(P<0.01)$ for cows fed Se-yeast than for cows fed selenate (Table 3). From a summary of 10 previous studies (Weiss, 2005), the concentration of Se in milk from cows fed Se-yeast was 1.9 times greater (median response) than for milk from cows fed selenite or selenate.

An interaction between DIM when milk was sampled and treatment was observed $(P<0.01)$. When colostrum was removed from the analysis, the interaction was not significant $(P>0.50)$. Therefore, this interaction was probably caused mostly by differences in treatment effects on colostrum compared with milk. The concentration of Se in colostrum from cows fed Se-yeast was approximately $0.06 \mathrm{mg} / \mathrm{L}$ greater than the concentra-
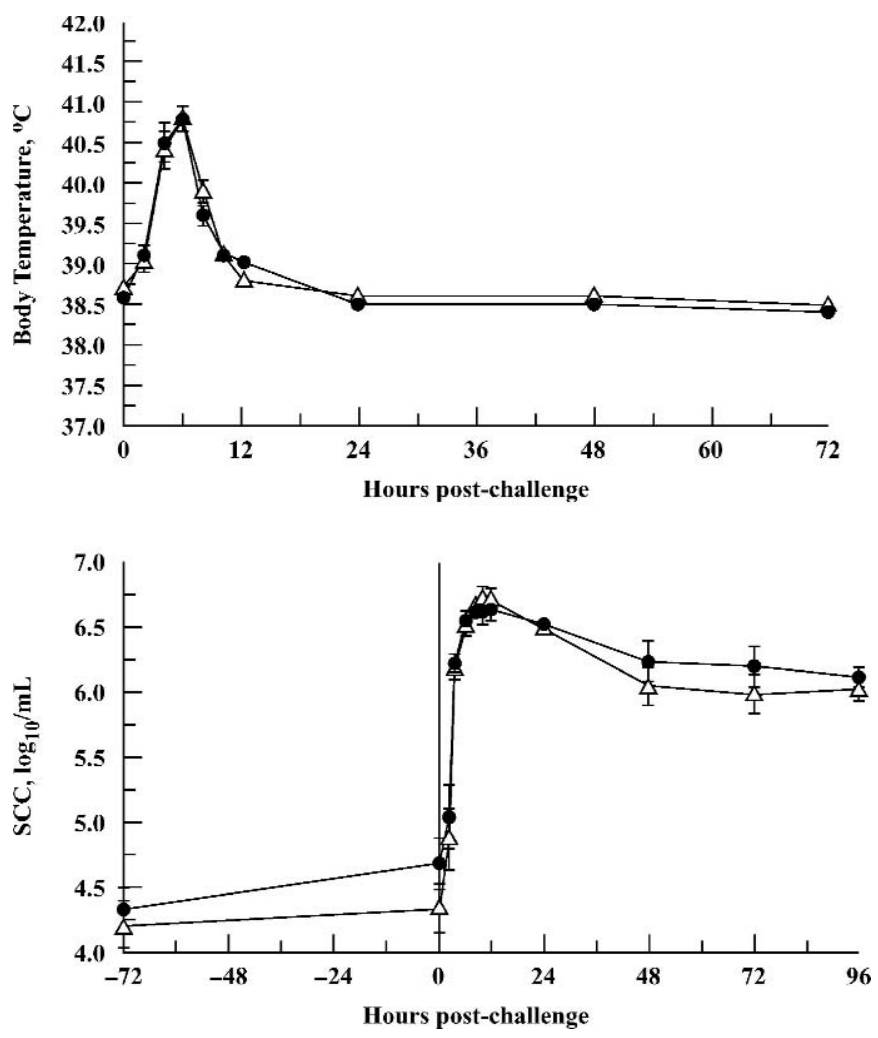

Figure 1. Body temperature and SCC before and after an intramammary infusion of LPS of cows fed selenate (open symbols) or Seyeast (closed symbols).

tion in colostrum from cows fed selenate. For milk, the difference averaged about $0.017 \mathrm{mg} / \mathrm{L}$. On a relative basis, however, the differences between treatments were similar for colostrum and milk. On average, the concentration of Se in colostrum and milk was about 1.8 times higher when cows were fed Se-yeast than when fed selenate.

\section{Serum Se in Calves}

The concentration of Se in serum at birth (before colostrum was fed) for calves from dams fed selenite were similar to values found previously (Weiss et al., 1984; Abdelrahman and Kincaid, 1995). Concentrations were greater $(P<0.01)$ for calves from dams fed Seyeast than for those from dams fed selenite (Table 3 ). The difference (37\%) was the same as that measured in serum from cows. Concentrations of serum Se in the calf at birth were moderately correlated with serum concentrations of Se of the dam at parturition $\left(\mathrm{r}^{2}=0.35\right.$; $P<0.01)$ The concentration of Se in whole blood of beef calves born from cows fed Se-yeast was 1.2 (Awadeh et al., 1998) to 1.85 (Gunter et al., 2003) times greater than that for calves from dams fed selenite. Concentration of 
Table 4. Effect of Se source on production measures.

\begin{tabular}{lcccc}
\hline & Selenate & Se-yeast & SEM & $P<$ \\
\hline DMI, kg/d & 16.1 & 15.3 & 0.6 & 0.13 \\
Milk, kg/d & 35.5 & 33.5 & 2.4 & 0.11 \\
Milk fat, \% & 5.40 & 5.33 & 0.18 & NS $^{3}$ \\
Milk protein, $\%$ & 3.10 & 3.02 & 0.11 & NS \\
Cow BW, ${ }^{1} \mathrm{~kg}$ & & & & \\
Dry-off $(60$ d prepartum) & 675 & 637 & 17 & 0.05 \\
3 d prepartum & 701 & 576 & 17 & 0.05 \\
3 DIM & 610 & 504 & 17 & 0.05 \\
28 DIM & 544 & 42.1 & 17 & 0.05 \\
Calf BW at 3 d, ${ }^{2} \mathrm{~kg}$ & 43.3 & 47.4 & 0.8 & $\mathrm{NS}$ \\
Age at weaning, d & 49.0 & 0.61 & 0.3 & NS \\
Calf BW gain, ${ }^{2} \mathrm{~kg} / \mathrm{d}$ & 0.63 & & & \\
\hline
\end{tabular}

${ }^{1}$ Cow BW were also analyzed as a repeated measures experiment with treatment $(P<0.05)$, day $(P<$ $0.05)$, and the interaction $(P>0.50)$ included in the model.

${ }^{2}$ Body weight, weaning age, and gain are for female calves only ( $\mathrm{n}=9$ and 8 for selenate and Se-yeast treatments, respectively). Mean BW at birth for all calves (male and female) was 43.7 and $44.2 \mathrm{~kg}$ for selenate and Se-yeast treatments, respectively.

${ }^{3} P>0.15$.

Se in serum from calves increased by $3 \mathrm{~d}(P<0.01)$, but no change was observed in treatment differences (time by treatment interaction, $P=0.20$ ). During those $3 \mathrm{~d}$, calves were fed only colostrum from their dams; therefore, Se intake by calves from cows fed Se-yeast was about 1.7 times greater (approximately $0.3 \mathrm{mg} / \mathrm{d}$ ) than Se intake by calves from dams fed selenite. The concentration of Se in serum of calves at $3 \mathrm{~d}$ of age were correlated with concentration of Se in colostrum $\left(\mathrm{r}^{2}=\right.$ $0.58 ; P<0.01)$ and with the concentration of serum Se of their dam at calving $\left(\mathrm{r}^{2}=0.23 ; P<0.05\right)$.

\section{Production Measures}

No differences were observed between treatments for milk yield, milk composition, or DMI (Table 4). Cows fed selenite had greater BW $(P<0.05)$, but this difference was likely caused by differences in BW before the experiment started. The numerical differences in DMI and milk yield also were likely caused by differences in BW. Dry matter intake as a percentage of BW averaged 2.8 for both treatment groups. Growth rate of female calves did not differ among treatments, but age at weaning was slightly less for calves from cows fed Se-yeast than for those from cows fed selenate.

\section{Neutrophil Function and Response to Challenge}

The percentage of neutrophils that phagocytized $E$. coli was not affected by treatment and averaged about 88\% (Table 5). Neutrophils from cows fed selenate tended $(P<0.09)$ to have more intracellular bacteria than neutrophils from cows fed Se-yeast. This increase did not translate into increased bacterial kill, which was virtually identical between groups and averaged
78\%. Most studies (Gyang et al., 1984; Grasso et al., 1990; Hogan et al., 1990) that compared phagocytosis in neutrophils from cattle supplemented with selenite or selenate with those not supplemented with Se reported no effect, suggesting that the differences we observed in this experiment may not be biologically relevant. Conversely, direct and indirect measures of bacterial kill are usually higher in neutrophils isolated from cattle supplemented with Se (from selenite or selenate) compared with those from unsupplemented cattle (Gyang et al., 1984; Grasso et al., 1990; Hogan et al., 1990). The lack of a treatment effect on bacterial killing ability observed in this study suggests that Se status with respect to neutrophil function was similar for both groups even though significant differences were observed in Se concentrations in serum. Malbe et al. (1995) also reported that form of supplemental Se (Seyeast or selenite) had no effect on phagocytosis and killing of Staphylococcus aureus by bovine neutrophils, although concentrations of Se in whole blood and milk were, respectively, 1.8 and 2.7 times greater for cows fed Se-yeast than for cows fed selenite.

The intramammary challenge with LPS elicited a short-term inflammatory reaction in the cows (Figures 1 and 2). Body temperature spiked at $10 \mathrm{~h}$ post-challenge (approximately $41^{\circ} \mathrm{C}$ ) and returned to normal by $24 \mathrm{~h}$ post-challenge. Milk SCC was elevated by $2 \mathrm{~h}$ postchallenge and reached peak concentrations by $12 \mathrm{~h}$ postchallenge. Concentrations decreased after $12 \mathrm{~h}$ but remained high throughout the 4-d post-challenge period. Dry matter intake was about $10 \%$ lower on the day of challenge (Figure 2). Milk production the first full day (a.m. and p.m. milkings) following challenge was reduced 15\%. Day had a significant $(P<0.05)$ effect on 
Table 5. Effect of Se source on neutrophil function. ${ }^{1}$

\begin{tabular}{lccll}
\hline & Selenate & Se-yeast & SEM & $P<$ \\
\hline Positive neutrophils, \% & 88.9 & 88.3 & 1.4 & NS \\
Intracellular bacteria/neutrophil, no. & 5.77 & 5.29 & 0.21 & 0.09 \\
Phagocytic index & 5.10 & 4.68 & 0.19 & 0.12 \\
Bacteria killed, \% & 77.7 & 78.6 & 1.3 & NS \\
\hline
\end{tabular}

${ }^{1}$ Positive neutrophils are those that contained at least one bacterium (Escherichia coli 487 ). Intracellular bacteria/neutrophil is the average number of bacteria in neutrophils that contained at least one bacterium. Phagocytic index was calculated by multiplying intracellular bacteria/neutrophil by (positive neutrophils/ 100 ). Intracellular kill was determined as number of dead, phagocytized bacteria/(number of live + number of dead intracellular bacteria) $\times 100$.

both DMI and milk yield, but treatment and the treatment $\times$ day interaction were not significant $(P>0.20)$. Overall clinical responses were very similar to those observed in other experiments when LPS was infused into the mammary gland (Chaiyotwittayakun et al., 2002). Treatment had no effect on any clinical measure of inflammation at any point.

Several studies (Erskine et al., 1987; Weiss et al., 1990a; Cebra et al., 2003) have reported statistically significant relationships between concentrations of Se in whole blood or plasma and measures of mastitis or neutrophil function. In studies showing significant rela-
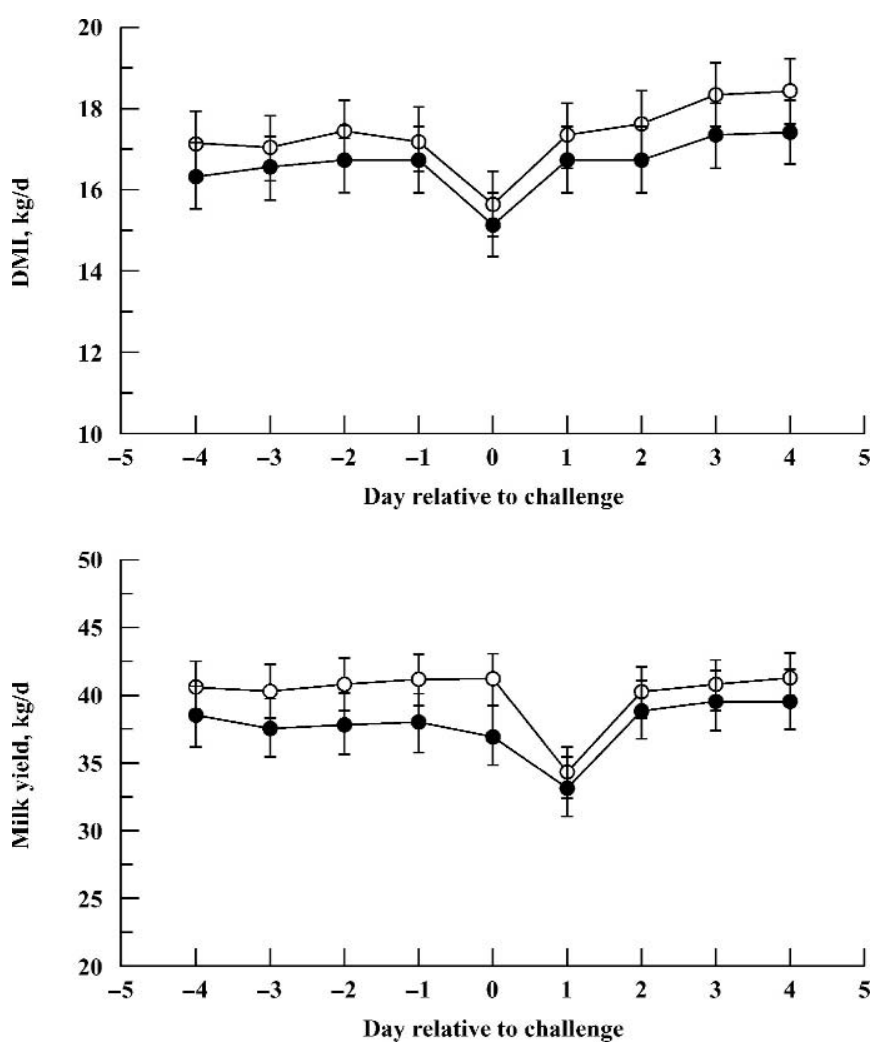

Figure 2. Dry matter intake and milk production before and after an intramammary infusion of LPS for cows fed selenate (open symbols) or Se-yeast (closed symbols). tionship, herds with higher concentrations of Se in whole blood or plasma had lower SCC (Erskine et al., 1987; Weiss et al., 1990a) or cows with higher concentrations of whole blood Se had higher superoxide production by neutrophils, an indirect measure of killing ability (Cebra et al., 2003). In those 3 studies, inorganic Se was the only form of supplemental Se provided to the cows.

There are at least 3 possible reasons for the lack of a treatment effect on neutrophil function or inflammatory response in light of significant differences in serum Se concentrations. First, cows on both treatments might have been in adequate Se status so that the increased serum Se concentrations observed when Se-yeast was fed provided no additional benefit. This is unlikely because mean serum Se concentrations for cows in the present experiment ( 0 and $28 \mathrm{~d}$ ) were at the very low end of the ranges reported in 2 (Erskine et al., 1987; Weiss et al., 1990a) of the 3 studies just discussed that reported significant relationships between blood Se and neutrophil function or SCC (mean values were near the high end of the range in the other study). In addition, the concentration of Se in serum for both groups at calving were lower than what is considered (Stowe and Herdt, 1992) adequate and remained lower than adequate for cows in the selenate group on 28 DIM. However, the lack of a negative control (i.e., treatment without supplemental Se) precludes eliminating this possibility. A second possible reason is that the difference in serum Se concentration between treatments was not great enough to cause differences in neutrophil function or inflammatory responses. This also is unlikely because the relative range (highest value divided by lowest value) in the 3 cited studies was between 1.4 and 2.0 compared with 1.4 for the present study.

A third possible reason is that the form of supplemental Se fed (selenate vs. Se-yeast) confounds interpretation of blood concentration data. The majority of Se in Se-yeast products is in the form of Se-Met (Rayman, 2004). No evidence exists that mammalian cells can differentiate Se-Met from methionine during protein synthesis; therefore, absorption of Se-Met from the in- 
testine can result in incorporation of Se during protein synthesis into any protein that contains methionine (Behne and Kyriakopoulos, 2001). When inorganic Se is fed, the Se is more likely to be associated with selenospecific proteins. Approximately $84 \%$ of the Se in erythrocytes from sheep fed selenite was associated with GSH-px (a seleno-specific protein) compared with 64\% when sheep were fed an equal amount of Se from highSe wheat (presumably mostly in the form of Se-Met) (van Ryssen et al., 1989). When inorganic Se is fed, activity of GSH-px and plasma Se concentrations are strongly correlated (Scholz and Hutchinson, 1979). In a previous experiment (Nicholson et al., 1991a), the concentration of Se in plasma was $26 \%$ higher $(P<0.01)$ in dairy cows fed Se-fertilized alfalfa than in cows fed unfertilized alfalfa plus inorganic Se, but GSH-px activity was not statistically different. In a literature summary, whole blood GSH-px activity was statistically increased in only 2 of 12 studies when cattle were fed Se-yeast rather than inorganic Se (Weiss, 2005).

When Se-yeast is fed, the Se-Met in blood is being used for general protein synthesis (e.g., casein). If the Se in Se-Met is to be used for seleno-specific proteins, the Se-Met must be catabolized, and then the Se can be incorporated into Se-cysteine for insertion into the active site of seleno-enzymes (Sunde and Evenson, 1987). Therefore, Se concentrations in blood of cows fed Se-yeast reflect a general pool (i.e., Se-Met) and a Sespecific pool. Selenium in the general pool should be less related to immune function than the Se-specific pool.

\section{CONCLUSIONS}

Mean concentrations of Se in serum from cows and serum from newborn calves from those cows was approximately 1.4 greater when Se-yeast was fed compared with selenate. Concentrations in colostrum and milk were between 1.5 and 2.0 times greater for cows fed Se-yeast. These differences, however, did not translate into differences in neutrophil function or clinical responses following an intrammary challenge with LPS.

\section{REFERENCES}

Abdelrahman, M. M., and R. L. Kincaid. 1995. Effect of selenium supplementation of cows on maternal transfer of selenium to fetal and newborn calves. J. Dairy Sci. 78:625-630.

Association of Official Analytical Chemists. 1990. Association of Official Analytical Chemists. 1990. Official Methods of Analysis. Vol. 1 15th ed. AOAC, Arlington, VA.

Awadeh, F. T., R. L. Kincaid, and K. A. Johnson. 1998. Effect of level and source of dietary selenium on concentrations of thyroid hormones and immunoglobulins in beef cows and calves. J. Anim. Sci. 76:1204-1215.

Behne, D., and A. Kyriakopoulos. 2001. Mammalian selenium-containing proteins. Annu. Rev. Nutr. 21:453-473.

Cebra, C. K., J. R. Heidel, R. O. Crisman, and B. V. Stang. 2003. The relationship between endogenous cortisol, blood micronutrients, and neutrophil function in postparturient Holstein cows. J. Vet. Intern. Med. 17:902-907.

Chaiyotwittayakun, A., R. J. Erskine, P. C. Bartlett, T. H. Herdt, P. M. Sears, and R. J. Harmon. 2002. The effect of ascorbic acid and L-histidine therapy on acute mammary inflammation in dairy cattle. J. Dairy Sci. 85:60-67.

Erskine, R. J., R. J. Eberhart, L. J. Hutchinson, and R. W. Scholz. 1987. Blood selenium concentrations and glutathionine peroxidase activities in dairy herds with high and low somatic cell counts. J. Am. Vet. Med. Assoc. 190:1417-1421.

Goldner, M., H. Farkas-Himsley, A. Kormendy, and M. Skinner. 1983 Bacterial phagocytosis monitored by fluorescence and extracellular quenching: ingestion and intracellular killing. Lab. Med. 14:291-294.

Grasso, P., R. W. Scholz, R. J. Erskine, and R. J. Eberhart. 1990 Phagocytosis, bactericidal activity, and oxidative metabolism of mammary neutrophils from dairy cows fed selenium-adequate and selenium-deficient diets. Am. J. Vet. Res. 51:269-275.

Gunter, S. A., P. A. Beck, and J. M. Phillips. 2003. Effects of supplementary selenium source on the performance and blood measurements in beef cows and their calves. J. Anim. Sci. 81:856-864.

Gyang, E. O., J. B. Stevens, S. D. Tsitsamis, and E. A. Usenik. 1984 Effects of selenium-vitamin E injection on bovine polymorphonucleated leukocytes phagocytosis and killing of Staphylococcus aureus. Am. J. Vet. Res. 45:175-177.

Hogan, J. S., K. L. Smith, W. P. Weiss, D. A. Todhunter, and W. L. Shockey. 1990. Relationships among vitamin E, selenium, and bovine blood neutrophils. J. Dairy Sci. 73:2372-2378.

Hogan, J. S., D. A. Todhunter, K. L. Smith, P. S. Schoenberger, and R. A. Wilson. 1992. Susceptibility of Escherichia coli isolated from intramammary infections to phagocytosis by bovine neutrophils. J. Dairy Sci. 75:3324-3329.

Ivancic, J., and W. P. Weiss. 2001. Effect of dietary sulfur and selenium concentrations on selenium balance of lactating Holstein cows. J. Dairy Sci. 84:225-232.

Knowles, S. O., N. D. Grace, K. Wurms, and J. Lee. 1999. Significance of amount and form of dietary selenium on blood, milk, and casein selenium concentrations in grazing cows. J. Dairy Sci. 82:429437.

Koh, T. S., and T. H. Benson. 1983. Critical re-appraisal of fluormetric method for determination of selenium in biological materials. J. Assoc. Offic. Anal. Chem. 66:918-926.

Malbe, M., M. Klaassen, W. Fang, V. Myllys, M. Vikerpuur, K. Nyholm, W. Sankari, K. Suoranta, and M. Sandholm. 1995. Comparisons of selenite and selenium yeast feed supplements on Se-incorporation, mastitis, and leukocyte function in Se-deficient dairy cows. J. Vet. Med. (Ser. A) 42:111-121.

National Research Council. 2001. Nutrient Requirements of Dairy Cattle. 7th rev. ed. ed. Natl. Acad. Press, Washington, DC.

Nicholson, J. W., A. M. S. Laurent, R. E. McQueen, and E. Charmley. 1991a. The effect of feeding organically bound selenium and $\alpha$ tocopherol to dairy cows on susceptibilty of milk to oxidation. Can. J. Anim. Sci. 71:135-143.

Nicholson, J. W., R. E. McQueen, and R. S. Bush. 1991b. Response of growing cattle to supplementation with organically bound or inorganic sources of selenium or yeast cultures. Can. J. Anim. Sci. 71:803-811.

Ortman, K., and B. Pehrson. 1999. Effect of selenate as a feed supplement in dairy cows in comparison to selenite and selenium yeast. J. Anim. Sci. 77:3365-3370.

Rayman, M. P. 2004. The use of high-selenium yeast to raise selenium status: How does it measure up? Br. J. Nutr. 92:557-573.

SAS. 1999. SAS/STAT User's Guide, Version 8. SAS Inst., Inc., Cary, NC.

Scholz, R. W., and L. J. Hutchinson. 1979. Distribution of glutathione peroxidase activity and selenium in the blood of dairy cows. Am. J. Vet. Res. 40:245-249.

Smith, K. L., J. H. Harrison, D. D. Hancock, D. A. Todhunter, and H. R. Conrad. 1984. Effect of vitamin E and selenium supplementation on incidence of clinical mastitis and duration of clinical symptoms. J. Dairy Sci. 67:1293-1300. 
Stowe, H. D., and T. H. Herdt. 1992. Clinical assessment of selenium status of livestock. J. Anim. Sci. 70:3928-3933.

Sunde, R. A., and J. K. Evenson. 1987. Serine incorporation into the selenocysteine moiety of glutathione peroxidase. J. Biol. Chem. 262:933-937.

van Ryssen, J. B. J., J. T. Deagen, M. A. Beilstein, and P. D. Whanger. 1989. Comparative metabolism of organic and inorganic selenium by sheep. J. Agr. Food Chem. 37:1358-1363.

Vendeland, S. C., J. A. Butler, and P. D. Whanger. 1992. Intestinal absorption of selenite, selenate, and selenomethionine in the rat. J. Nutr. Biochem. 3:359-365.
Weiss, W. P. 2005. Selenium sources for dairy cattle. Pages 61-71 in Proc. Tri-State Dairy Nutr. Conf., Ft. Wayne, IN. Dept. of Anim. Sci., The Ohio State Univ., Columbus.

Weiss, W. P., V. F. Colenbrander, and M. D. Cunningham. 1984. Maternal transfer and retention of supplemental selenium in neonatal calves. J. Dairy Sci. 67:416-420.

Weiss, W. P., J. S. Hogan, K. L. Smith, and K. H. Hoblet. 1990a. Relationships among selenium, vitamin $\mathrm{E}$, and mammary gland health in commercial dairy herds. J. Dairy Sci. 73:381-390.

Weiss, W. P., D. A. Todhunter, J. S. Hogan, and K. L. Smith. 1990b. Effect of duration of supplementation of selenium and vitamin $\mathrm{E}$ on periparturient dairy cows. J. Dairy Sci. 73:3187-3194. 